\title{
PEMBERIAN EKSTRAK DAUN KELOR TERHADAP PENINGKATAN KADAR HEMOGLOBIN PADA REMAJA PUTRI PUTUS SEKOLAH USIA 12 - 18 TAHUN
}

\author{
Yulianti Anwar $^{1 凶}$, Veni Hadju², Samrichar R ${ }^{1}$, Andi Alimuddin Unde ${ }^{3}$, Andi Nilawati Usman ${ }^{1}$, \\ Ni Luh Putu Herli Mastuti ${ }^{4}$
}

\author{
${ }^{1}$ Program Studi Magister Kebidanan Universitas Hasanuddin Makassar \\ ${ }^{2}$ Fakultas Kesehatan Masyarakat Universitas Hasanuddin Makassar \\ ${ }^{3}$ LP2M Universitas Hasanuddin Makassar \\ ${ }^{4}$ Fakultas Kedokteran Universitas Brawijaya Malang
}

\section{ARTICLE INFO \\ Article history \\ Submitted : 2020-08-05 \\ Revised : 2020-08-31 \\ Accepted : 2020-12-28 \\ Keywords: \\ Moringa leaf extract Hemoglobin levels Young women Drop Out}

\section{Kata Kunci: \\ Ekstrak daun kelor Kadar hemoglobin Remaja putri Putus sekolah}

\begin{abstract}
Teenage girls are prospective mothers who will give birth to the nation's next generation. Anemia among teenage girls causes the risk of giving birth to low birth weight babies (LBW) so that it has an impact on the optimal quality of life (bleeding, infection, abortion, low birth weight, premature, and defects congenital). Moringa leaves contain high amounts of vitamin A, vitamin C, vitamin B, calcium, potassium, iron, and protein which are easily digested and assimilated by the human body. Moringa oleifera based supplements have an impact on pregnant women and prevent adverse pregnancy outcomes. The purpose of this study was to determine the effect of Moringa leaves extract on increasing hemoglobin levels in teenage girls who drop out of school. This quantitative research was true experimental with the design used was the Randomized Controlled Double-Blind Pre-Posttest by looking after 2 months intervention of giving Moringa leaves extract to teenage girls dropping out of school. The sample criteria used based on the inclusion criteria were obtained as many as 30 teenage girls who dropped out of school which was divided into 15 interventions or given extract moringa leaves a dose of $2 \times 1$ with a content of $1000 \mathrm{mg}$ and 15 controls or given TTD with a dose of $2 \times 1$ with a content of $1000 \mathrm{mg}$. The analysis used univariate analysis and bivariate analysis. Then the data collected in this study was processed analytically with a Paired T-test and Independent T-Test. The results showed the difference in hemoglobin levels between the intervention group $(p=0.000)$ and the control group $(\mathrm{p}=0.011)$. The feeding of Moringa leaves extract capsules had the effect of increasing hemoglobin levels after 2 months of intervention.

Remaja putri penderita anemia, sebagai calon ibu yang akan melahirkan generasi penerus bangsa, anemia menyebabkan risiko melahirkan bayi berat lahir rendah (BBLR) sehingga berdampak pada kualitas hidup yang optimal (perdarahan, infeksi, abortus, berat badan lahir rendah, prematur, maupun cacat bawaan). Daun kelor mengandung vitamin A, vitamin C, vitamin B kalsium, kalium, besi dan protein dalam jumlah sangat tinggi yang mudah dicerna dan diasimilasi oleh tubuh manusia. Moringa oleifera yang berbasis suplemen memiliki dampak pada wanita hamil dan mencegah hasil kehamilan yang merugikan. Tujuan penelitian ini untuk mengetahui pengaruh ekstrak daun kelor terhadap peningkatan kadar hemoglobin pada remaja putri putus sekolah. Penelitian ini merupakan penelitian kuantitatif dengan jenis penelitian true experiment dengan desain yang digunakan adalah Randomized Controlled Double Blind Pre-Posttest dengan melihat setelah 2 bulan intervensi pemberian ekstrak daun kelor pada remaja putri putus sekolah. Kriteria sampel yang digunakan berdasarkan kriteria inklusi diperoleh sebanyak 30 orang remaja putri putus sekolah yang dibagi menjadi 15 intervensi atau diberikan ekstrak daun kelor dengan dosis 2x1 dengan kandungan 1000 mg dan 15 kontrol atau diberikan TTD dengan dosis 2x1 dengan kandungan $1000 \mathrm{mg}$. Analisis yang digunakan adalah dengan cara analisis univariat dan analisis bivariat kemudian data yang dikumpulkan dalam penelitian ini diproses secara analitik dengan uji T Paired dan Uji T Test Independent. Hasil penelitian menunjukkan bahwa perbedaan kadar hemoglobin antara kelompok intervensi $(\mathrm{p}=0.000)$ dan kelompok kontrol $(\mathrm{p}=0.011)$. Pemberian kapsul ekstrak daun kelor berpengaruh untuk meningkatkan kadar hemoglobin setelah 2 bulan intervensi.
\end{abstract}


Corresponding Author:

Yulianti Anwar

Program Studi Magister Kebidanan Universitas Hasanuddin Makassar

Telp. 081342386726

Email: fadiyah_fadillah@yahoo.co.id

\section{PENDAHULUAN}

Remaja putri banyak mengalami kekurangan zat-zat gizi dalam konsumsi makanan sehari-harinya. Remaja putri umumnya mengalami kekurangan zat besi, kalsium, dan vitamin A. Di samping itu, juga kekurangan vitamin B6, seng, asam folat, iodium, vitamin D dan magnesium. Salah satu dari empat masalah gizi yang sedang dihadapi negara-negara berkembang. Termasuk Indonesia, adalah masalah anemia zat gizi besi. Di Indonesia prevalensi anemia pada remaja putri mencapai 26,50\% (Depkes, 2010).

Laporan data Riset Kesehatan Dasar (RISKESDAS, 2018), prevalensi anemia di Indonesia yaitu $48,9 \%$ dengan penderita anemia berumur $15-24$ tahun sebesar $84,6 \%$. Secara Nasional perilaku konsumsi makanan tertentu pada penduduk umur $\geq 10$ tahun paling banyak mengonsumsi bumbu penyedap $(77,3 \%)$, diikuti makanan dan minuman manis $(53,1 \%)$ dan makanan berlemak (40,7\%) (Kemenkes, 2013). Sedangkan pada Dinas Kesehatan Provinsi Sulawesi Selatan pangan jajanan berkontribusi terhadap pemenuhan kebutuhan energi sebesar $31,1 \%$ dari protein sebesar 27,4\% (Profil Kesehatan Sulawesi Selatan, 2013).

Laporan data Riset Kesehatan Dasar (Riset Kesehatan Dasar ( RISKESDAS ) Tahun 2013, 2014), prevalensi anemia di Indonesia yaitu $21,7 \%$ dengan penderita anemia pada Wanita Usia Subur ( WUS ) antara 15 - 49 tahun adalah usia $15-24$ tahun $(18,4 \%)$, usia 25 - 34 tahun $(16,9 \%)$ dan usia $35-44$ tahun $(18,3 \%)$, jumlah anemia pada ibu hamil di Indonesia cukup tinggi yakni sebesar $37,1 \%$ dari total secara nasional (Riset Kesehatan Dasar (RISKESDAS) Tahun 2013, 2014).

Remaja dengan gejala anemia dapat mengeluh letih, lemah, pucat, sensitif terhadap dingin, anoreksia, pusing dan sakit kepala, stomatitis dan glositis. Untuk menghindari hal yang tidak diinginkan maka perlu ditangani segera dengan asupan nutrisi yang baik sesuai kebutuhan antara lain makanan yang mengandung zat besi dan protein yang cukup (bahan pangan hewani: daging, ikan, telur, kacang-kacangan) dan sayuran berwarna hijau yang mengandung mineral dan vitamin (Fitri, 2012).

Daun kelor mengandung vitamin $\mathrm{A}$, vitamin $\mathrm{C}$, vitamin $\mathrm{B}$, kalsium, kalium, besi dan protein dalam jumlah sangat tinggi yang mudah dicerna dan diasimilasi oleh tubuh manusia. Daun kelor adalah daun dari pohon kelor yang mengandung berbagai zat gizi makro dan mikro serta bahan-bahan aktif yang bersifat sebagai antioksidan. Menggandung nutrisi penting seperti zat besi (fe) 28, $2 \mathrm{mg}$, kalsium (ca) 2003,0 mg dan vitamin A 16,3 mg kaya $\beta$ karoten, protein vitamin $\mathrm{A}, \mathrm{C}, \mathrm{D}, \mathrm{E}, \mathrm{K}$ dan $\mathrm{B}$ (tiamin, riboflan, niasin, asam pantotenat, biotin, vitamin B6, vitamin B 12 dan folat. Berbagai jenis senyawa antioksidan seperti asam askorbat, flavonoid, fenolat dan karotenoid (Almatsier, 2010).

Menurut penelitian yang dilakukan oleh (Muhammad et al., 2018) mengatakan bahwa suplemen asam folat dan zat besi sangat luas digunakan untuk pencegahan anemia, tetapi moringa oleifera yang berbasis suplemen mungkin memiliki dampak pada wanita hamil dan mencegah hasil kehamilan yang merugikan. Moringa Oleifera telah secara signifikan meningkatkan konsentrasi hemoglobin pada wanita anemia.

Belum ada penelitian yang melakukan penelitian mengenai pemberian ekstrak daun kelor terhadap peningkatan kadar hemoglobin pada remaja putus sekolah usia 12 - 18 tahun dan juga masih tingginya prevalesi anemia pada remaja putri di Indonesia yang dapat mengakibatkan tidakkesiapan remaja putri secara fisik dan psikologis dalam menghadapi pra konsepsi, kehamilan, persalinan dan masa nifas sehingga peneliti tertarik ingin meneliti untuk melihat pengaruh pemberian ekstrak daun kelor terhadap peningkatan kadar hemoglobin pada remaja putus sekolah usia 12 -18 tahun.

\section{METODE PENELITIAN Jenis Penelitian}

Penelitian ini merupakan penelitian kuantitatif dengan jenis penelitian true experiment dengan desain yang digunakan adalah Randomized Controlled Double Blind Pre-Posttest. 


\section{Lokasi dan Waktu Penelitian}

Penelitian ini dilakukan di Kecamatan Polobangkeng Utara, Kabupaten Takalar, Provinsi Sulawesi Selatan. Waktu penelitian ini dilakukan dari bulan Maret sampai dengan Mei 2020.

\section{Populasi dan Sampel}

Populasi dalam penelitian ini adalah seluruh remaja putri putus sekolah usia $12-18$ tahun di Kecamatan Polobangkeng Utara, Kabupaten Takalar, Provinsi Sulawesi Selatan sebanyak 75 orang. Sampel dalam penelitian ini adalah sebagian populasi dari remaja putri yang termasuk dalam kriteria inklusi yakni remaja putri yang tidak bersekolah/putus sekolah, remaja putri yang bersedia menjadi responden dalam penelitian dan menyetujui informed consent, usia 12 - 18 tahun, remaja putri yang mengalami anemia ringan, remaja putri yang tidak menjalani program diet.

Untuk kriteria eksklusi adalah remaja yang tidak memiliki alergi terhadap kelor dan mengonsumsi suplemen dan herbal penambah darah lainnya di Kecamatan Polobangkeng Utara, Kabupaten Takalar, Provinsi Sulawesi Selatan yang awalnya 40 orang menjadi 30 orang karena keadaan wabah Covid-19 pada saat post intervensi.

\section{Pengumpulan Data}

Data sekunder diperoleh dari catatan Kantor Camat Polobangkeng. Data primer diperoleh secara langsung dari responden yang dikumpulkan melalui selembar kuesioner untuk mendapatkan data dan dilakukan pengukuran kadar Hemoglobin dengan cara menggunakan HemoCue untuk mengetahui anemia atau tidak.

\section{Pengolahan dan Analisis Data}

Teknik analisis data dilakukan dengan menggunakan analisis univariat dan bivariat. Analisis univariat dilakukan untuk mendapatkan gambaran umum dengan cara mendeskripsikan tiap variabel yang digunakan dalam penelitian dengan melihat gambaran distribusi frekuensi baik variabel dependen maupun variabel independen.

Analisis bivariat adalah analisis yang dilakukan untuk melihat hubungan dua variabel yaitu antara variabel bebas dan variabel terikat. Data yang dikumpulkan dalam penelitian ini terlebih dahulu dilakukan uji normalitas setelah itu diproses secara analitik dengan uji $T$ paired dan uji T Test Independent.

\section{HASIL PENELITIAN}

Berdasarkan Tabel 1 untuk kelompok umur mayoritas responden pada kelompok kontrol berumur $16-18$ tahun sebanyak 10 orang atau sebesar $66.6 \%$ sedangkan pada kelompok intervensi mayoritas berumur 16 18 tahun sebanyak 8 orang atau sebesar 53.3\%. Kemudian untuk pendidikan terakhir responden pada kelompok kontrol mayoritas pada tingkat SD, tidak tamat SMP dan SMP sebanyak masing-masing 5 orang dengan persentase masing-masing $33.3 \%$, kelompok intervensi juga demikian yakni pendidikan terakhir responden berada pada tahap SD dan SMP masing-masing 5 orang dengan persentase $33.3 \%$. Selanjutnya untuk pendidikan terakhir orang tua pada kelompok kontrol mayoritas berada pada tahap SD, tidak tamat SMP dan SMP masing-masing 4 orang dengan persentase $26.6 \%$ sedangkan untuk kelompok intervensi mayoritas untuk pendidikan terakhir orang tua yakni SMP sebanyak 5 orang atau $33.3 \%$.

Pada karakteristik pekerjaan orang tua untuk kelompok kontrol mayoritas memiliki pekerjaan sebagai petani penggarap yakni sebanyak 7 orang atau $46.6 \%$ sedangkan untuk kelompok intervensi mayoritas memiliki pekerjaan sebagai buruh harian sebanyak 6 orang atau sebesar $40 \%$. Selanjutnya untuk wilayah Desa dimana sampel/responden berdomisili untuk kelompok kontrol mayoritas berada di wilayah Desa Komara yakni sebanyak 9 orang atau sebesar $60 \%$, sedangkan untuk kelompok intervensi mayoritas berada di wilayah Desa Komara yakni sebanyak 8 orang atau sebesar 53.3\%.

Pada tabel 2. menunjukkan perubahan kadar $\mathrm{Hb}$ pada kelompok kontrol sebesar 7 orang (46.6\%) dengan peningkatan kadar Hemoglobin $0.1-0.5$ gr/dl sedangkan pada kelompok kode B perubahan kadar hemoglobin sebesar 6 orang $(40 \%)$ dengan peningkatan kadar hemoglobin $1.1-2.0 \mathrm{gr} / \mathrm{dl}$.

Tabel 3. menunjukkan hasil uji paired $t$ test pada kelompok control dengan nilai $p$ value 0.011 sehingga dapat disimpulkan bahwa ada perbedaan antara sebelum dan sesudah pemberian TTD ( $\mathrm{P}$ value < 0.05 ). Hal ini dapat dilihat dari nilai mean pada pre $9.88 \mathrm{gr} / \mathrm{dl}$ mengalami kenaikan pada saat setelah pemerian TTD selama 60 hari dengan nilai mean 10.18 
$\mathrm{gr} / \mathrm{dl}$. Untuk hasil uji paired $\mathrm{t}$ test pada kelompok intervensi dengan nilai $\mathrm{p}$ value 0.000 sehingga dapat disimpulkan bahwa ada perbedaan signifikan antara sebelum dan sesudah pemberian Kapsul Ekstrak Daun Kelor ( $\mathrm{P}$ value $<0.05$ ). Hal ini dapat dilihat dari nilai mean pada pre $9.59 \mathrm{gr} / \mathrm{dl}$ mengalami kenaikan pada saat setelah pemerian kapsul ekstrak daun kelor selama 60 hari dengan nilai mean 11.27 $\mathrm{gr} / \mathrm{dl}$.
Berdasarkan hasil analisis uji independent t-test pada tabel didapatkan nilai perbedaan rata-rata selisih kadar hemoglobin pada kelompok intervensi 1.68 dan kelompok kontrol 0.3. Hasil analisis tersebut juga menunjukkan p value < $0.05 @ 0.000$, maka Ho ditolak dan $\mathrm{Ha}$ diterima yang artinya ada pengaruh pemberian ekstrak daun kelor terhadap peningkatan kadar hemoglobin pada remaja putus sekolah.

Tabel 1. Distribusi Karakteristik Responden $(n=30)$

\begin{tabular}{|c|c|c|c|c|}
\hline \multirow{3}{*}{ Karakteristik } & \multicolumn{4}{|c|}{ Kelompok } \\
\hline & \multicolumn{2}{|c|}{ Kontrol } & \multicolumn{2}{|c|}{ Intervensi } \\
\hline & $\mathbf{n}$ & $\%$ & $\mathbf{n}$ & $\%$ \\
\hline \multicolumn{5}{|l|}{ Umur (Tahun) } \\
\hline $12-15$ & 5 & 33.3 & 7 & 46.6 \\
\hline $16-18$ & 10 & 66.6 & 8 & 53.4 \\
\hline Total & 15 & 100.0 & 15 & 100.0 \\
\hline \multicolumn{5}{|l|}{ Pendidikan Terakhir Anak } \\
\hline SD & 5 & 33.3 & 5 & 33.3 \\
\hline Tidak Tamat SMP & 5 & 33.3 & 4 & 26.6 \\
\hline SMP & 5 & 33.3 & 5 & 33.3 \\
\hline SMA & 0 & 0 & 1 & 6.6 \\
\hline Total & 15 & 100.0 & 15 & 100.0 \\
\hline \multicolumn{5}{|c|}{ Pendidikan Terakhir Orang Tua } \\
\hline Tidak Tamat SD & 2 & 13.3 & 3 & 20 \\
\hline $\mathrm{SD}$ & 4 & 26.6 & 3 & 20 \\
\hline Tidak Tamat SMP & 4 & 26.6 & 3 & 20 \\
\hline SMP & 4 & 26.6 & 5 & 33.3 \\
\hline Tidak Tamat SMA & 1 & 6.6 & 1 & 6.6 \\
\hline Total & 15 & 100.0 & 15 & 100.0 \\
\hline \multicolumn{5}{|l|}{ Pekerjaan Orang Tua } \\
\hline Buruh Harian & 5 & 33.3 & 6 & 40 \\
\hline Tukang Kayu & 1 & 6.6 & 3 & 20 \\
\hline Petani Penggarap & 7 & 46.6 & 5 & 33.3 \\
\hline Petani & 2 & 13.3 & 1 & 6.6 \\
\hline Total & 15 & 100.0 & 15 & 100.0 \\
\hline \multicolumn{5}{|l|}{ Desa } \\
\hline Balangtanaya & 5 & 33.3 & 6 & 40 \\
\hline Komara & 9 & 60 & 8 & 53.3 \\
\hline Massamanturu & 1 & 6.6 & 1 & 6.6 \\
\hline Total & 15 & 100.0 & 15 & 100.0 \\
\hline
\end{tabular}

\section{PEMBAHASAN}

Penelitian ini membahas tentang pengaruh pemberian ekstrak daun kelor terhadap peningkatan kadar haemoglobin pada remaja putri putus sekolah usia $12-18$ tahun di Kec. Polobangkeng Utara, Kab. Takalar, Prov. Sulawesi Selatan.
Perubahan kadar $\mathrm{Hb}$ pada kelompok kontrol sebesar 7 orang (46.6\%) dengan peningkatan kadar Hemoglobin $0.1-0.5 \mathrm{gr} / \mathrm{dl}$ sedangkan pada kelompok kode B perubahan kadar hemoglobin sebesar 6 orang (40\%) dengan peningkatan kadar hemoglobin $1.1-2.0$ gr/dl. Hal ini membuktikan bahwa pada kelompok intervensi yang diberikan kapsul 
ekstrak daun kelor dapat meningkatkan kadar hemoglobin dalam darah, di bandingkan dengan kelompok kontrol yang diberikan TTD, sehingga kapsul ekstrak daun kelor baik diberikan pada remaja putri terutama yang mengalami anemia ringan.

Hal ini juga membuktikan bahwa kelompok kontrol yang mengonsumsi Tablet Tambah Darah dapat meningkatkan kadar hemoglobin pada remaja putri karena setiap TTD berisi Ferrous Fumarate $60 \mathrm{mg}$, asam folat 400 mcg. Sedangkan Ekstrak daun kelor mengandung banyak unsur nutrisi yang salah satunya tidak dimiliki tablet tambah darah yakni Vitamin C dimana untuk setiap 100 gr mengandung $1549.47 \mathrm{mg}$ yang berfungsi mempercepat penyerapan zat besi sehingga kadar hemoglobin lebih cepat meningkat.

\section{Tabel 2. Distribusi Perubahan Kadar Hemoglobin Pre Post pada Kelompok Kontrol dan Kelompok Intervensi}

\begin{tabular}{|c|c|c|c|c|}
\hline \multirow{3}{*}{ Karakteristik } & \multicolumn{4}{|c|}{ Kelompok } \\
\hline & \multicolumn{2}{|c|}{ Kontrol } & \multicolumn{2}{|c|}{ Intervensi } \\
\hline & $\mathbf{n}$ & $\%$ & $\mathbf{n}$ & $\%$ \\
\hline \multicolumn{5}{|l|}{ Perubahan Kadar HB ( gr/dl ) } \\
\hline$<0-0$ & 4 & 26.6 & 0 & 0 \\
\hline $0.1-0.5$ & 7 & 46.6 & 0 & 0 \\
\hline $0.6-1.0$ & 3 & 20 & 0 & 0 \\
\hline $1.1-1.5$ & 1 & 6.6 & 6 & 40 \\
\hline $1.6-2.0$ & 0 & 0 & 5 & 33.3 \\
\hline $2.1-2.5$ & 0 & 0 & 4 & 26.6 \\
\hline Total & 15 & 100.0 & 15 & 100.0 \\
\hline
\end{tabular}

Tabel 3. Distribusi Perbedaan Kadar Hemoglobin Pre Post pada Kelompok Kontrol Intervensi dan Perbedaan Rerata Kadar Hemoglobin

\begin{tabular}{lcccc}
\hline \multirow{2}{*}{ Kelompok } & \multicolumn{2}{c}{ Kadar Hemoglobin } & \multirow{2}{*}{ Selisih } & \multirow{2}{*}{ P Value } \\
\cline { 2 - 3 } & Pre & Post & & \\
\cline { 2 - 4 } & Mean \pm SD & Mean \pm SD & Mean \pm SD & \\
\hline Kontrol & $9.88 \pm 0.48$ & $10.18 \pm 0.69$ & $0.3 \pm 0.21$ & $0.011^{\mathrm{a}}$ \\
Intervensi & $9.59 \pm 0.49$ & $11.27 \pm 0.41$ & $1.68 \pm-0.08$ & $0.000^{\mathrm{a}}$ \\
P Value & $0.000^{\mathrm{b}}$ & & & \\
\hline
\end{tabular}

Dengan pemberian kapsul ekstrak daun kelor 2x1 dengan dosis $1000 \mathrm{mg}$ per hari selama 2 bulan atau 60 hari dianggap masih kurang atau belum bisa mengatasi anemia ini dikarenakan masih banyak faktor yang mempengaruhi di antaranya menstruasi, pola makan tidak teratur, gizi yang tidak seimbang juga karena faktor stres yang dialami remaja. Untuk itu perlu diupayakan agar dosis pada kapsul ekstrak daun kelor di tambah yakni menjadi $800 \mathrm{mg}$ per kapsul dengan konsumsi $2 \times 1$ per hari.

Jika terjadi anemia maka terjadi peningkatan penyerapan zat besi akibat tingginya kebutuhan sehingga terjadilah peningkatan setelah diberikan intervensi berupa kapsul ekstrak daun kelor dan kandungan vitamin $\mathrm{C}$ yang membantu dalam penyerapan zat besi (Wibowo et al., 2013).

Daun kelor memiliki potensi yang sangat baik untuk melengkapi kandungan nutrisi dalam tubuh, meningkatkan energi dan ketahanan tubuhnya serta untuk mengatasi keluhan akibat kekurangan mineral seperti kekurangan zat besi yang mengakibatkan anemia (Sylvie et al., 2013). Pada daun kelor yang dikeringkan memiliki kadar protein, zat besi, vitamin $\mathrm{A}$ dan vitamin $\mathrm{C}$ yang tinggi, sehingga sangat efektif untuk mengobati anemia defisiensi besi. Selain itu, daun ini tidak mengandung zat berbahaya sehingga tidak memiliki efek samping. Selama ini tidak pernah ditemukan kasus atau keracunan akibat mengonsumsi daun kelor (Sylvie et al., 2013). 
Konsumsi daun kelor (Moringa oleifera) merupakan salah satu alternatif untuk menanggulangi kasus kekurangan gizi di Indonesia. Hasil riset ilmiah modern membuktikan bahwa daun kelor adalah salah satu sumber pangan nabati yang kaya akan kandungan gizi. Hasil analisa Balbir S. Mathur menunjukkan bahwa daun kelor memiliki kandungan gizi yang sangat penting untuk menjaga berbagai macam penyakit (Sylvie et al., 2013).

Hasil uji paired $t$ test pada kelompok intervensi dengan nilai $\mathrm{p}$ value 0.000 sehingga dapat disimpulkan bahwa ada perbedaan signifikan antara sebelum dan sesudah pemberian Kapsul Ekstrak Daun Kelor (P value $<0.05)$. Hal ini dapat dilihat dari nilai mean pada pre $9.59 \mathrm{gr} / \mathrm{dl}$ mengalami kenaikan pada saat setelah pemerian kapsul ekstrak daun kelor selama 60 hari dengan nilai mean $11.27 \mathrm{gr} / \mathrm{dl}$.

Berdasarkan hasil analisis uji independent t-test pada tabel didapatkan nilai perbedaan rata - rata selisih kadar hemoglobin pada kelompok intervensi 1.68 dan kelompok kontrol 0.3. Hasil analisis tersebut juga menunjukkan p value<0.05@0.000, maka Ho ditolak dan Ha diterima yang artinya ada pengaruh pemberian ekstrak daun kelor terhadap peningkatan kadar hemoglobin pada remaja putus sekolah.

Hal di atas berhubungan dengan penelitian sebelumnya (Hasri et al., 2016) bahwa pemberian ekstrak daun kelor mempunyai pengaruh dalam kenaikan kadar hemoglobin pada remaja putri. Dimana nilai mean mengalami peningkatan dari $10.73 \mathrm{gr} / \mathrm{dl}$ pada awal pengukuran dan menjadi 12.35 di akhir pengukuran dengan selisih mean 1.61 $\mathrm{gr} / \mathrm{dl}$.

Adapun penelitian terdahulu tentang pemberian kapsul daun kelor kepada remaja putri anemia yang dilakukan oleh (Arini, 2018) bahwa pemberian kapsul daun kelor mempunyai pengaruh yang signifikan terhadap kadar hemoglobin dengan selisih mean sebesar 1. $39 \mathrm{mg} / \mathrm{dl}$ sedangkan pada penelitian ini dalam pemberian kapsul ekstrak daun kelor mempunyai selisih mean sebesar $1.68 \mathrm{mg} / \mathrm{dl}$ ini membuktikan bahwa dengan kandungan Vit $\mathrm{C}$ yang lebih banyak pada kapsul ektrak daun kelor lebih mudah dan membantu dalam penyerapan zat besi. Hal ini juga didukung oleh penelitian yang dilakukan (Zakaria et al., 2015) bahwa unsur nutrisi vitamin $\mathrm{C}$ per 100 gr pada ekstrak daun kelor lebih banyak yakni 1514,96 dibandingkan vitamin $\mathrm{C}$ pada tepung daun kelor hanya 17,3. Tablet Tambah Darah (Fe) diperlukan dalam tubuh untuk pertumbuhan, membantu kerja berbagai macam enzim dalam tubuh, menanggulangi infeksi, membantu kerja usus menetralisir zat-zat toksin dan yang paling penting untuk pembentukan hemoglobin (Dian \& Marizal, 2012).

Hasil uji paired t test pada kelompok control dengan nilai $\mathrm{p}$ value 0.011 sehingga dapat disimpulkan bahwa ada perbedaan antara sebelum dan sesudah pemberian TTD ( $\mathrm{P}$ value $<0.05)$. Hal ini dapat dilihat dari nilai mean pada pre $9.88 \mathrm{gr} / \mathrm{dl}$ mengalami kenaikan pada saat setelah pemberian TTD selama 60 hari dengan nilai mean $10.18 \mathrm{gr} / \mathrm{dl}$.

Penelitian tentang $\mathrm{Fe}$ Berdasarkan penelitian yang dilakukan oleh (Damayanti \& Siallagan, 2016) dengan judul pengaruh asupan $\mathrm{Fe}$, vitamin $\mathrm{A}, \mathrm{B} 12$ dan $\mathrm{C}$ terhadap Kadar Hemoglobin pada remaja Vegan bahwa setiap kenaikan $1 \mathrm{mg}$ asupan $\mathrm{Fe}$ akan menaikkan kadar $\mathrm{Hb}$ remaja di Pusdiklat Buddhis Maitreyawira sebesar 0,013 g/dl serta setiap penambahan $1 \mathrm{mg}$ asupan vitamin $\mathrm{C}$ akan meningkatkan kadar $\mathrm{Hb}$ remaja sebanyak 0,002 $\mathrm{g} / \mathrm{dl}$, sehingga menunjukkan hasil bahwa asupan zat besi dan vitamin $\mathrm{C}$ berhubungan signifikan dengan kejadian anemia pada remaja.

Berdasarkan penelitian Fikawati (2011) tentang pengaruh suplementasi zat besi satu dan dua kali per minggu terhadap kadar Hemoglobin pada siswi di Kota Tangerang yang menderita anemia diperoleh pada kelompok kontrol setelah diketahui 10\% mengalami anemia ringan, maka peneliti memberikan ekstrak daun kelor untuk dikonsumsi serta memberikan edukasi gizi sehingga ada perbaikan lanjutan status anemia ringan menjadi normal, sedangkan pada kelompok perlakuan sebelum intervensi status kadar $\mathrm{Hb} 30$ orang (100\%) mengalami anemia ringan dan setelah intervensi sebanyak 26 orang (87\%) dengan status $\mathrm{Hb}$ normal dan 4 orang $(13 \%)$ tetap mengalami anemia ringan walaupun ada peningkatan rata-rata berkisar $1.53 \mathrm{gr} / \mathrm{dl}$ dari ke 4 subjek.

Adapun penelitian yang dilakukan oleh (Irianty Tinna, 2018) mengenai perubahan kadar HB pada ibu hamil yang mengonsumsi tepung daun kelor+Fe pada kelompok intervensi dan pemberian $\mathrm{Fe}$ pada kelompok kontrol menunjukkan perbedaan rerata kadar 
$\mathrm{Hb}$ sebelum dan sesudah diberikan intervensi. Pada kelompok Kontrol didapatkan nilai mean sebelum diberi perlakuan sebesar 9,38 mg/dl dan mengalami penurunan nilai mean menjadi 9,30 $\mathrm{mg} / \mathrm{dl}$, dimana perbedaan ini tidak bermakna secara statistik dengan nilai $\mathrm{p}=0.244$ $>0,05$, sedangkan pada kelompok intervensi sebelum diberi perlakuan sebesar 9,74 mg/dl dan setelah diberikan perlakuan mengalami peningkatan nilai mean menjadi $9,93 \mathrm{mg} / \mathrm{dl}$, dimana perbedaan ini juga tidak bermakna secara statistik dengan nilai $\mathrm{p}=0,285>0,05$. Berdasarkan selisih mean kadar $\mathrm{Hb}$ diketahui bahwa pada kelompok kontrol mengalami penurunan rata-rata kadar $\mathrm{Hb}$ dari pengukuran pada saat pre ke post sebesar 0,08 gr/dl, sedangkan pada kelompok intervensi mengalami kenaikan rata-rata kadar $\mathrm{Hb}$ dari pre ke post sebesar $0,19 \mathrm{gr} / \mathrm{dl}$.

\section{KESIMPULAN DAN SARAN}

Pemberian kapsul ekstrak daun kelor berpengaruh untuk meningkatkan kadar hemoglobin setelah 2 bulan intervensi. Diharapkan kepada perangkat desa dan pihak puskesmas setempat agar memperhatikan dan aktif dalam melakukan kunjungan kepada remaja putri putus sekolah yang mengalami anemia. Memberikan edukasi secara update kepada remaja putri putus sekolah tentang pentingnya mengonsumi sayur-sayuran terutama daun kelor dan juga meningkatkan pemenuhan gizi seimbang serta PHBS kepada masyarakat juga edukasi tentang dampak atau bahaya seks bebas pada remaja secara aktif dan berkala.

\section{DAFTAR PUSTAKA}

Almatsier. (2010). Prinsip Dasar Ilmu Gizi. Gramedia Pustaka Utama.

Arini. (2018). Pengaruh Pemberian Tepung Daun Kelor (Moringa Oleifera Leaves) Terhadap Peningkatan Kadar Hemoglobin Pada Remaja Putri Di Kecamatan Tamalatea Kabupaten Jeneponto. Universitas Hasanuddin Makassar.

Damayanti, \& Siallagan. (2016). Pengaruh Asupan Zat Besi, Vitamin A, Vitamin B12 dan Vitamin $C$ Dengan Kadar Hemoglobin pada Remaja Vegan di Pusdiklat Buddhis Maitreyawira.

Dian, \& Marizal. (2012). Anemia Defisiensi Besi. Jurnal Kesehatan Masyarakat Program Studi Ilmu Kesehatan Masyarakat FK Unad. Yogyakarta.

Fitri, A. R. (2012). Gizi Dan Kesehatan Reproduksi (1st ed.). Cakrawala Ilmu.

Hasri, Y., Veni, H., \& Ema, A. (2016). Pengaruh Ekstrak Daun Kelor Terhadap Peningkatan Kadar Haemoglobin Pada Remaja Putri Di SMU Muhammadiyah Kupang. ISSN Jurnal Kesehatan.

Kemenkes. (2013). Prevalensi Anemia Pada Remaja Di Indonesia. Badan Litbangkes Kemenkes RI.

Muhammad, N. S., Andi, T. A. I., \& Veni, H. (2018). Supplementations On Pregnant Women And The Potential Of Moringa Oleifera Supplement To Prevent Adverse Pregnancy Outcome. International Journal of Science And Healthcare Research, 3(1). www.ijshr.com.

Profil Kesehatan Sulawesi Selatan. (2013). Dinas Kesehatan Propinsi Sulawesi Selatan.

Kemenkes RI. (2018). Hasil Utama RISKESDAS. Kementerian Kesehatan Indonesia.

Riset Kesehatan Dasar (RISKESDAS) Tahun 2013. (2014). Kementerian Kesehatan Indonesia.

Sylvie, P. S., Rivotta, W., \& Vera, H. T. (2013). Efektivitas Suplementasi Bubuk Daun Kelor (Moringaoleifera) terhadap Peningkatan Kadar Haemoglobin Pada Ibu Hamil Yang Menderita Anemia. 5(1).

Wibowo, Notoatmojo, \& Rohamani. (2013). Hubungan Antara Status Gizi Dengan Anemia Pada Remaja Putri Di SMP Muhammadiyah 3 Semarang. Jurnal Kedokteran Muhammadiyah, 1(2).

Zakaria, Hadju, V., S, A., \& B, B. (2015). The Effect Of Moringa Leaf Extract in Breasfeeding Mother Againts Anemia Status And Breast Milk Iron Content. IJSBAR, 24(1). 